\title{
Identifying the Factors Affecting Entrepreneurial Attitude of Athlete \& Non-athlete University Students
}

\author{
${ }^{*}$ Reza Mohammad kazemi ${ }^{1}$, Siroos Madandar² \\ ${ }^{1}$ University of Tehran, Iran \\ 2University of Tarbiat e Moalem, Iran \\ *r_mkazemi@ut.ac.ir
}

\begin{abstract}
Considering entrepreneurship as a state of mind, we have to admit that nowadays, apart from business and economy, any person can think and act in an entrepreneurial manner. Hence, not only the "entrepreneurship enhancing" policies should not be confined to higher education levels, but also they have to be included in elementary and non-athlete programs. In this study, the level of entrepreneurial attitude, and the effect of some demographic variables on it were investigated among a group of 406 university students in Tehran. The main tool used in this study was the translated Athyde's ATE questionnaire (attitude towards entrepreneurial business initialization) which was tested for reliability by a pretest and computation of Cronbach's Alpha coefficient for the main study and all its components. The results showed that the level of entrepreneurial attitude was above average among athlete students, in all of the investigated aspects and components. They also showed that variables such as gender, having a self-employed father, employment status of mother, and the type of university (athlete \&non-athlete) have no significant impact on the level of entrepreneurial attitude in students.
\end{abstract}

Keywords: Entrepreneurial attitude, Need for achievement, internal locus of control, Leadership, Creativity

\section{Introduction}

Today developing entrepreneurship and entrepreneurial culture is considered as a key strategic policy in front of different countries. Moreover, developing entrepreneurial capacities has an special importance for creating innovation stabilizing comparative advantage in economics of the world (Drennan et al ,2004) General translation of the word "entrepreneurship" has drawn special attention on the aspect of job making and business creation. Whereas the concept of entrepreneurship includes a more comprehensive and deep meaning, which is not limited to job creation and engagement in business creation? This misunderstanding of the real concept of entrepreneurship and existence of unemployed human resources in the society, especially obvious unemployment of educated people, lead to a downright attention on job making when adopting the policies through development process. While entrepreneurship has some other substantial positive consequences like proliferation of the creativities, persuasion and development of innovations, increasing of self-confidence, creation and development of technology, wealth creation and growth of the public welfare as well. Today, we should consider entrepreneurship as a set of subjective intellectuals. (Dahlgren, 1999) Such a distinct point of view from business and economic basis, leads in the fact that everyone could think and act in an entrepreneurial way. Therefore, the European commission has defined entrepreneurship in its perspective documents for year 2004 as a general view that is applicable in any kinds of business activities and routine lifetimes (Fuchs et al, 2008). One of the most important measures of development and growth of entrepreneurship in any society is preparation of a comfortable entrepreneurial infrastructure, in which creation of entrepreneurial culture is an important aspect. Entrepreneurial culture is a combination of values, perspective, norms and behaviors shaping the personal identity of entrepreneurs. Development plans should not be concentrated only on higher education students, but also on the primary and non-athlete ones (Linan et al. 2010). Development of entrepreneurship can be improved by increasing development of positive perception of possibility of entrepreneurship through comfortable teaching and other educational activities in lower ages (Rasheed, 2000). Fewer measures are considered through progressing entrepreneurial mentality in general public level. Evidently, compulsory education could not be a comfortable basis for a person to become an entrepreneur. Most students in primary education levels are not well experienced or mature enough to understand complex conditions of business management context. Therefore, entrepreneurial attitude can be considered as a good option for implementing current education system (Johannisson \& Madsen, 2000). Scholars like Ajzen (1991), Ajzen \& Fishbein (1977), and Rosenberg and Howland (1960), defined attitude as a stance of preparation and tendency that generally will cause to the situation of acceptance or denied in respect to subject of attitude itself. 
According to this definition, we can say that entrepreneurial attitude is a stance, which according to that people will show entrepreneurial behavior. The main purpose of this research is to evaluate entrepreneurial attitude level of second and third level primary education non-athlete students and vocations of the second educational zone in Tehran and accessing the role of demographic variables in forecasting it.

\section{Literature Review}

Different researcher grading entrepreneurs normally see entrepreneurs with their own special and different viewpoints, and classify the cause of being entrepreneurs in different manners. Some scholars, such as Stewart et al. (1998), believe that psychological traits cause to some good results in foreseeing people's attitude toward entrepreneurship. However, Robinson et al. (1991) express that basis of entrepreneurship research, which grounded, on the theories of personality, included two basic problems. One of these problems is that, these theories are not specially created for accessing entrepreneurship. (Homaday, 1987; Homaday \& Nunnally, 1987) and are not describing human, environment counter effects. Some other researchers tried to define entrepreneurs specifications, focuses on demographic factors and famous as a permanent perspective. This viewpoint supposed behavior as a permanent factor, or the subject which is hardly under the effects of demographic factors such as, gender, race or birth ordinance; whereas the results someone has gained through entrepreneurship is not especially constant, but also these results may change under the state of new or past appearing experiences(Robinson et al, 1991). Robinson et al (1991) argue that those psychological researches and those researches on entrepreneur's personality should be more dynamic. He personally adhered to this belief that research in this area should take a more dynamic approach toward entrepreneurship subject. Attitudes are less dynamic in comparison with personality and demographic traits and proportionate to time sand different conditions, changes in action and reaction with environment (Rosenberg \& Havland, 1960). According to Robinson et al.'s pattern (1991), attitude is the subject, which is of considerable importance in entrepreneurship field. In 1991, Robinson et al. grounded EAO measure's designation, for evaluation of entrepreneurial attitude of individuals based on attitude models. In entrepreneurship studies Robinson et al. (1991) were the first group of scholars used the concept of attitude in this name and according to attitude three sectional including cognition, behavior and sensation. They introduced the attitudinal approach for anticipation of entrepreneurship, according to critics, which two past approaches including personality traits and demographic approach prone to. They did claim that attitudinal theories with a high level of reliability, which had a wide use in it, could be introduced as a more dynamic and rich approach with prediction nature in anticipation of entrepreneurial behaviors. Even if many scholars (Drucker, 1970; Gasse, 1985; Greenberger\& Sexton, 1987; Olson \& Bosserman, 1984) introduced the importance of attitudes in studying the subject of entrepreneurship and identifying of entrepreneurs, but there were only a limited group of them using the attitudinal theories as an alternatives to psychological models, which were based on personality traits. The models of Gasse (1985), Greenberger, and Sexton (1987), can be considered as attitudinal models, which concentrated only on cognitive section of attitude. Although, in 2009, a new model designed for evaluation of student's entrepreneurial potential, based on Robinson's model, and called it as AT. Athayde (2009) had been trying to make the conceptualization for entrepreneurial potentials compatible, in a way to be comfortable for students.

Entrepreneurship Dimensions: Defining successful entrepreneurs is usually the main center of behaviors combined with special skills and traits including creativity, inner control (independency), and leadership. This is unusual or different, dealing with ambiguity and uncertainty (Gibb, 1987, 1993, 2000, 2002). The following research considered different factors for entrepreneurial attitude. These factors include ones like need for achievement, personal control, innovation, self-confidence (Robinson et al, 1991) attitude toward self-efficacy, inner control, creativity, leadership, and intuition (Athayde, 2009). In addition, some factors such as attitude toward earning money, competition (Rivalry), change and entrepreneurship (Schwarz et al, 2009) and other considerable traits like risk taking (Olson \& Bosserman, 1984) are included. While some other, researchers believe in factors like self-effectiveness, differentiability (Florin et al, 2007) and inner independency (Norasmah et al. 2008). Considering the population under study in this research is student is the Athayde's model (2009), have been used, which evaluates student's entrepreneurial attitude dimensions in three aspects: sensational, cognitive, and behavioral. 
Figure 1: Research Conceptual model based on Athayde ATE model (2009)

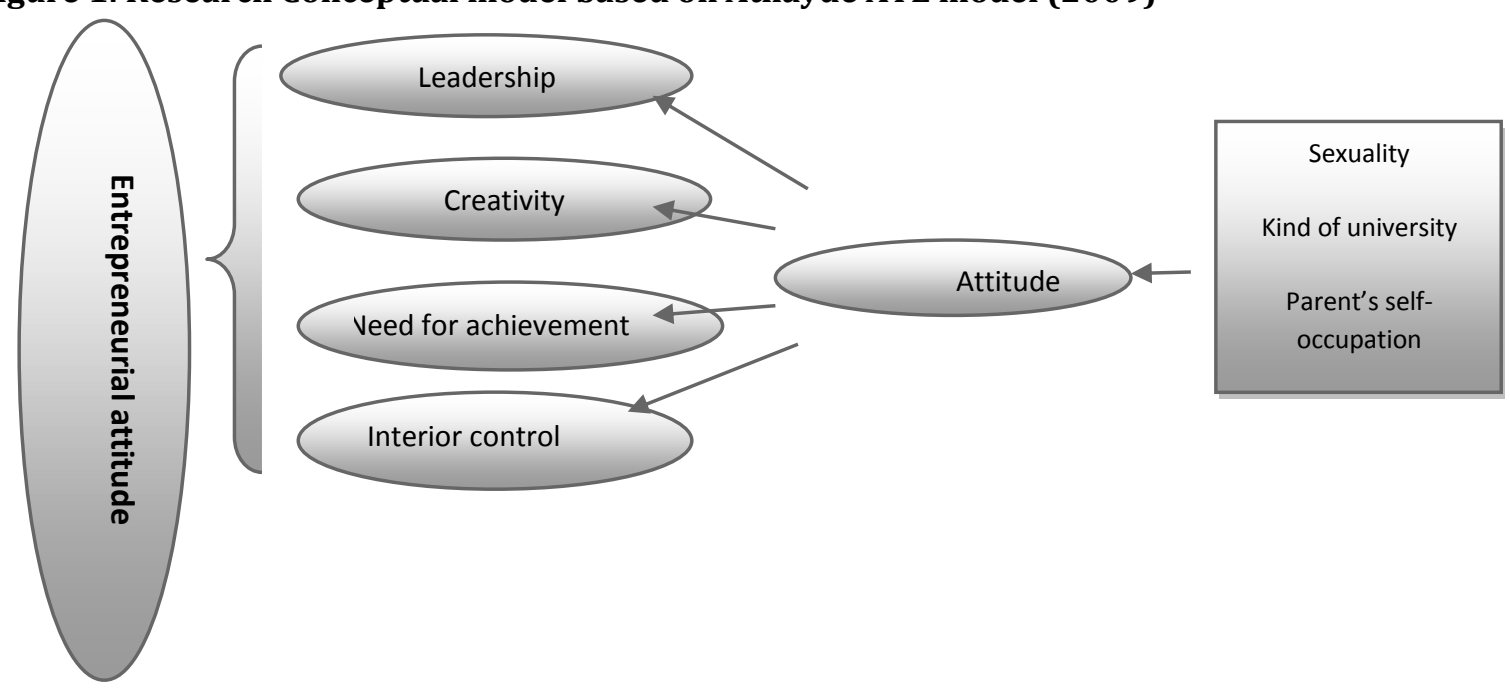

Creativity: Creativity is shaped of regular ingredients in two new combinations. Attending some special commitments or beneficiaries (Mednick, 1996) Timmons and Spinelli (2004) express creativity as the heart of entrepreneurship concept. This concept widely studied in various researches and studies relating to entrepreneurship (Caird, 1991). Personal creativity is the precursor of innovative behaviors and creativity and defining as an important dimension in entrepreneurial potential.

Center of interior control: Interior control is defined as follow (Carton \& Nowicki, 1994): The concept of inner control (center of interior control) has been used as an attitude by Robinson et al (1991) and as a basic dimension of entrepreneurship. Entrepreneurs considered as someone with more interior control (Gasse, 1985, Brockhaus, 1982).

Need for achievement: Wilder (1989) defined Need for achievement as follows: tendency and thirsty or a serious attempt proposed by someone through gaining a goal or dominating things, people, beliefs, circumstances or one excelsior scale or criterion. Need for achievement is a provocation which is forcing someone to do activities and duties that include a full trying, expression of needed skills that should be proposed through the shade of smooth risk and creation of a clear outcome. (Shane 2007).Many researchers have defined the need for achievement as an important trait of entrepreneurs (Caird, 1991).

Leadership: Leadership is an ability of affecting other people to achieve their goals (Northouse, 2007). Chio et al. (2003) defined "leadership" as an important entrepreneurship factor and expressed entrepreneurship as a kind of leadership (in SME's) that works according to special arrangements. This viewpoint defined leadership as a key dimension of entrepreneurship. Timmons and Spinelli (2004) have identified leadership as one of the necessary conditions for creation of novel businesses; and have related it to skills such as team making, creation of confidence and commitment and self-motivation.

\section{Methodology}

According to our data collection method, here we faced a descriptive research and considering the use of consequences and findings this study have classified as a practical research, which leads in practical implications. Considering this fact that population under study includes university students, for evaluation of their entrepreneurial attitudes, Athayde's model (2009) have been used as the basis for our study. In this research, Athayde's(2009) standard questionnaire have been used, combining 18 indexes which assess student's answer according to 5-point Likert scale to measure athlete \& non athlete students' entrepreneurial attitude, need for achievement, creativity, and leadership in three emotional, cognitive and behavioral sections. At first part of this questionnaire, some question have been arranged to collect demographic information of the statistical population. Second part of the questionnaire includes gender, type of universities (universities for athletes \& non-athletes), self-occupancy of father, or whether he is under employment and occupancy of mother, which is considered as independent variables of this research. 
Population and samples: Population of this research includes all public university students in Tehran. Cochran's formula have been used in determining the sample size of which is 375 , and 445 questionnaires have been used through maximizing the accuracy of the research and processing method have been used for sampling stage.

Table 1: Frequency distribution of the sample

\begin{tabular}{llllll}
\hline & Frequency & percentage & frequency & percentage \\
\hline Gender & & & Father's job status \\
female & 195 & $\% 48$ & Self-occupancy & 226 & $\% 56$ \\
male & 211 & $\% 52$ & Employee & 163 & $\% 40$ \\
total & 406 & \multicolumn{5}{c}{$\begin{array}{l}\text { No answer } \\
\text { University type }\end{array}$} & & Mother's job status & $\% 4$ \\
Non athlete university & 228 & $\% 56$ & Self-occupancy & 88 & $\% 22$ \\
Athlete university & 178 & $\% 44$ & housekeeper & 303 & $\% 74$ \\
total & 406 & & No answer & 15 & $\% 4$ \\
\hline
\end{tabular}

Table 1 reveals the frequency distribution of student statistical sample. Validity of questionnaire has been supported by specialists and scholars (Expert validity). Moreover, to prove the reliability, a pretest have been applied on 30 students which Cronbach's Alpha was equal to 0.06 for general test and more than 0.06 for subtests which generally shows an accepted reliability.

\section{Results}

Table 2: Entrepreneurial attitude averages and its dimensions and components

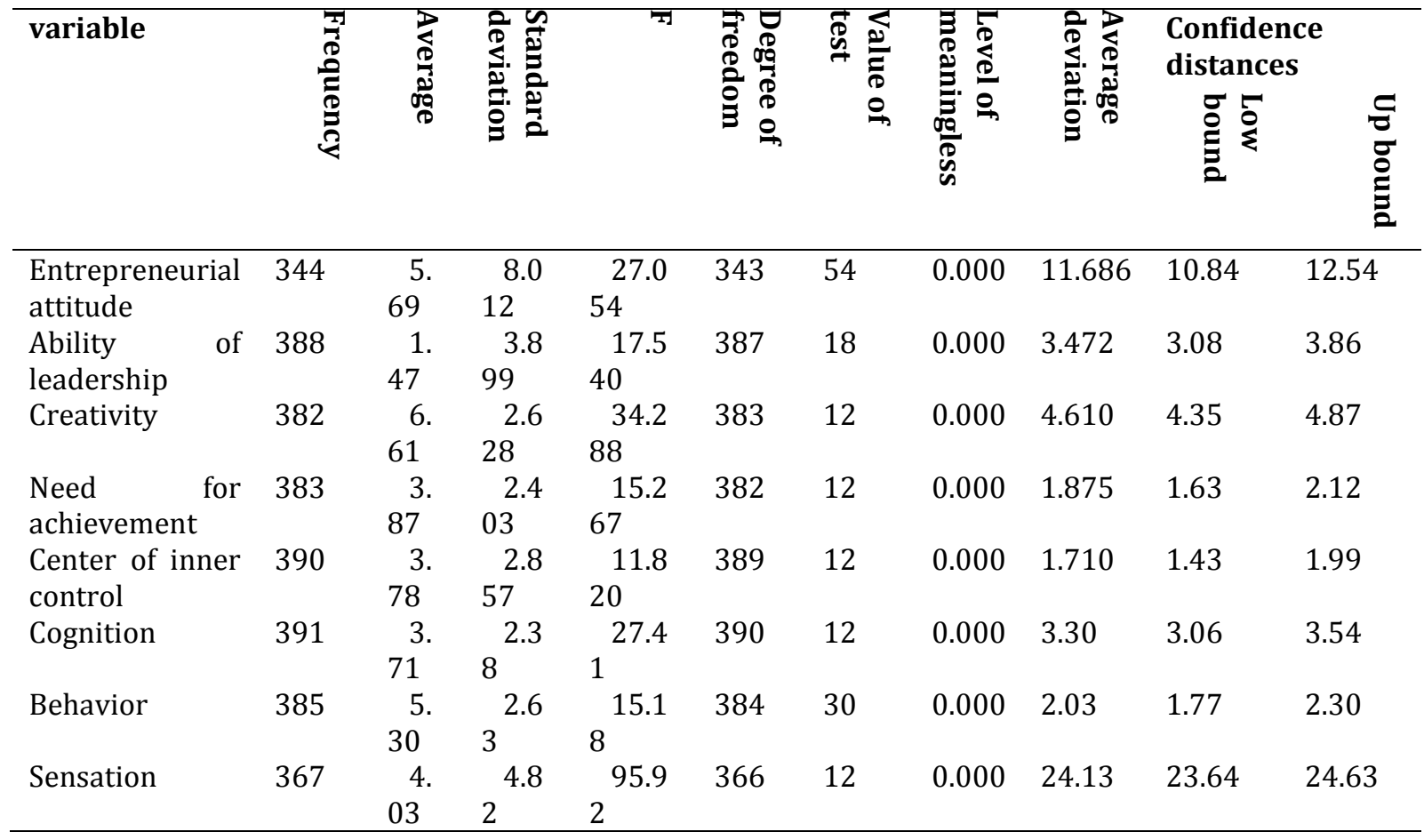

This research questionnaire have contained 18 indexes, and students answers were according to 5-pint Likert scale ranging from $1=$ complete disagreement to $5=$ complete agreement. According to number of indexes in each dimension, that dimension's scale calculated based on average amount which have signed as "three". In fact, test value has proved to an average level amount in each dimension. Thus, amounts more than this "measure" considered more than average. In addition, amounts less, seemed to be lower so. According to table 2, and numbers resulted as average indexes, and as the average test was meaningful; it has been shown that all dimensions of each student's entrepreneurship attitude average score (each students perception of their abilities in leadership, their attitude respect to creativity, the level of need for achievement in each students and the level of self-controlling did percept in each one) 
and all three components of entrepreneurship attitude (emotional, behavioral and cognition) are more than test value (scale amount). Therefore, the numbers are greater than average limit, Student's entrepreneurship attitude severance to demographical variables Comparing student's entrepreneurship attitude dimensions and components according to demographic variables (gender, kind of university, parents job). It should be noted that, T-test and Levin test have been used in this research.

Table 3: Comparison of student's entrepreneurship attitude according to gender and university type

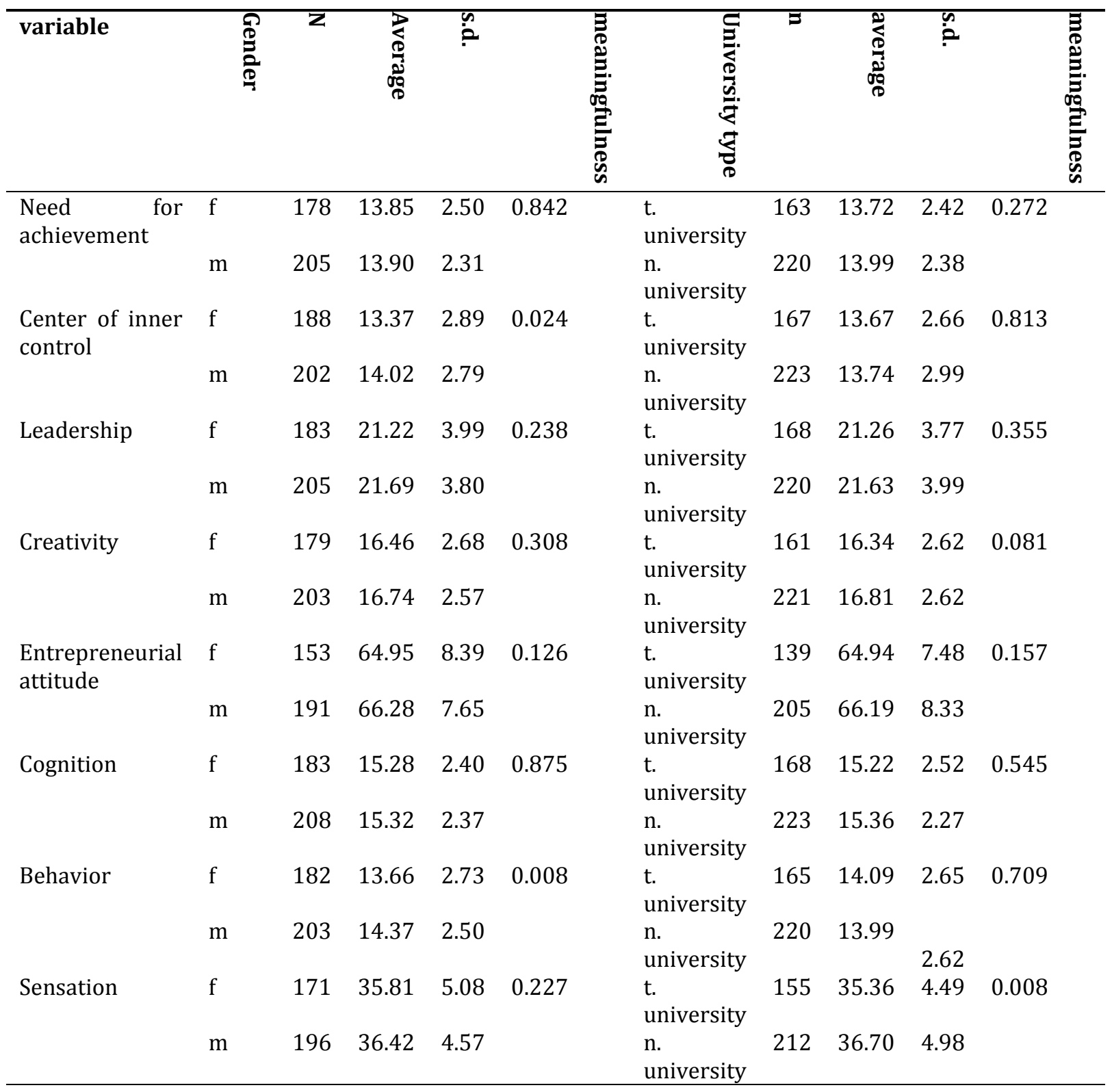

As you can see in table 3, such a meaningful difference exists between average scores of male and female students in central inner control dimension and behavioral section of entrepreneurship attitude. Male's average score is greater; differences in other dimensions and components are not meaningful. However, comparing to female students, average scores of male students in all dimensions and components of entrepreneurship attitude were greater. According to table 3, except in behavioral section case, which average score of athlete university students, was greater, non-athlete university students, in all other dimensions and components of entrepreneurship attitude had greater scores. According to the average comparison test, average scores of non-athlete and athlete university students, have a meaningful different in emotional section of entrepreneurship attitude only (Non-athlete student's average score was greater than athlete university students were). No meaningful different observed in all other dimensions and components of entrepreneurship attitude. 
Table 4: Comparison of student's entrepreneurship attitude according to their parent's occupations

\begin{tabular}{|c|c|c|c|c|c|c|c|c|c|c|}
\hline Variable & $\begin{array}{l}\frac{\pi}{2} \\
\stackrel{0}{0} \\
\frac{0}{0} \\
\frac{0}{0}\end{array}$ & $\bar{F}$ & 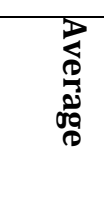 & $\ddot{a}$ & 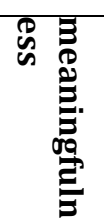 & $\begin{array}{l}3 \\
0 \\
\frac{5}{0} \\
\frac{0}{0} \\
\frac{0}{0}\end{array}$ & $=$ & 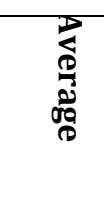 & $\ddot{\omega}$ & 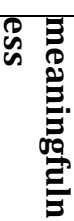 \\
\hline \multirow[t]{2}{*}{$\begin{array}{l}\text { Need for } \\
\text { achievement }\end{array}$} & \multirow{2}{*}{$\begin{array}{l}\text { Self } \\
\text {.occupancy } \\
\text { Employee }\end{array}$} & 212 & 13.97 & 2.33 & 0.355 & \multirow{2}{*}{$\begin{array}{l}\text { Self } \\
\text {.occupancy } \\
\text { housekeeper }\end{array}$} & 85 & 13.87 & 2.49 & \multirow[t]{2}{*}{$\begin{array}{l}0.88 \\
5\end{array}$} \\
\hline & & 155 & 13.74 & 2.51 & & & 284 & 13.83 & 2.39 & \\
\hline \multirow[t]{2}{*}{$\begin{array}{l}\text { Center of inner } \\
\text { control }\end{array}$} & \multirow{2}{*}{$\begin{array}{l}\text { Self } \\
\text {.occupancy } \\
\text { Employee }\end{array}$} & 217 & 13.69 & 2.71 & 0.763 & \multirow{2}{*}{$\begin{array}{l}\text { Self } \\
\text {.occupancy } \\
\text { housekeeper }\end{array}$} & 88 & 13.84 & 3.12 & \multirow[t]{2}{*}{$\begin{array}{l}0.59 \\
8\end{array}$} \\
\hline & & 157 & 13.78 & 3.05 & & & 289 & 13.66 & 2.76 & \\
\hline \multirow[t]{2}{*}{ leadership } & \multirow{2}{*}{$\begin{array}{l}\text { Self } \\
\text { occupancy } \\
\text { Employee }\end{array}$} & 217 & 21.36 & 3.89 & 0.398 & \multirow{2}{*}{$\begin{array}{l}\text { Self } \\
\text {.occupancy } \\
\text { housekeeper }\end{array}$} & 84 & 21.57 & 3.86 & \multirow{2}{*}{$\begin{array}{l}0.77 \\
5\end{array}$} \\
\hline & & 155 & 21.70 & 3.81 & & & 291 & 21.43 & 3.92 & \\
\hline \multirow[t]{2}{*}{ creativity } & \multirow{2}{*}{$\begin{array}{l}\text { Self } \\
\text {.occupancy } \\
\text { Employee }\end{array}$} & 214 & 16.43 & 2.67 & 0.066 & \multirow{2}{*}{$\begin{array}{l}\text { Self } \\
\text {.occupancy } \\
\text { housekeeper }\end{array}$} & 83 & 16.86 & 2.38 & \multirow[t]{2}{*}{$\begin{array}{l}0.28 \\
7\end{array}$} \\
\hline & & 152 & 16.93 & 2.38 & & & 286 & 16.51 & 2.68 & \\
\hline \multirow[t]{2}{*}{$\begin{array}{l}\text { Entrepreneurial } \\
\text { attitude }\end{array}$} & \multirow{2}{*}{$\begin{array}{l}\text { Self } \\
\text {.occupancy } \\
\text { Employee }\end{array}$} & 194 & 65.32 & 7.67 & 0.266 & \multirow{2}{*}{$\begin{array}{l}\text { Self } \\
\text {.occupancy } \\
\text { housekeeper }\end{array}$} & 78 & 65.86 & 8.45 & \multirow[t]{2}{*}{$\begin{array}{l}0.75 \\
9\end{array}$} \\
\hline & & 137 & 66.31 & 8.18 & & & 255 & 65.54 & 7.87 & \\
\hline \multirow[t]{2}{*}{ cognition } & \multirow{2}{*}{$\begin{array}{l}\text { Self } \\
\text {.occupancy } \\
\text { Employee }\end{array}$} & 217 & 15.24 & 2.22 & 0.435 & \multirow{2}{*}{$\begin{array}{l}\text { Self } \\
\text {.occupancy } \\
\text { housekeeper }\end{array}$} & 87 & 15.26 & 2.23 & \multirow[t]{2}{*}{$\begin{array}{l}0.97 \\
8\end{array}$} \\
\hline & & 158 & 15.43 & 2.40 & & & 290 & 15.27 & 2.43 & \\
\hline \multirow[t]{2}{*}{ behavior } & \multirow{2}{*}{$\begin{array}{l}\text { Self } \\
\text {.occupancy } \\
\text { Employee }\end{array}$} & 215 & 13.91 & 2.56 & 0.248 & \multirow{2}{*}{$\begin{array}{l}\text { Self } \\
\text {.occupancy } \\
\text { housekeeper }\end{array}$} & 84 & 14.23 & 2.45 & \multirow[t]{2}{*}{$\begin{array}{l}0.37 \\
6\end{array}$} \\
\hline & & 153 & 14.32 & 2.66 & & & 287 & 13.94 & 2.69 & \\
\hline \multirow[t]{2}{*}{ Sensation } & \multirow{2}{*}{$\begin{array}{l}\text { Self } \\
\text {.occupancy } \\
\text { Employee }\end{array}$} & 206 & 36.10 & 4.58 & 0.811 & \multirow{2}{*}{$\begin{array}{l}\text { Self } \\
\text {.occupancy } \\
\text { housekeeper }\end{array}$} & 290 & 36.43 & 5.26 & \multirow[t]{2}{*}{$\begin{array}{l}0.48 \\
2\end{array}$} \\
\hline & & 147 & 36.23 & 5.11 & & & 275 & 36.00 & 4.68 & \\
\hline
\end{tabular}

According to table 4, in general level testing, and considering all dimensions and components, average scales of entrepreneurship attitude test for students whose fathers are business owner have a meaningful different comparing to average scale of students whose fathers work as employees. Because level of meaningfulness for all dimensions and components of entrepreneurial attitude is greater than .05 , all dimensions and components of entrepreneurship attitude except need for achievement, average scales of students whose fathers work as employees is greater than students whose fathers are business owner. Entrepreneurship attitude average scales of students whose mothers are business owner, in all dimensions and components, are greater than students mothers work as employees. However, this different is not meaningful in any dimensions and components, because level of meaningfulness for all dimensions and components of entrepreneurship attitude is greater than .05. Pearson correlation coefficient has been used to show the relation between variables and the consequences reflected in table 5.Consequencesreflect that generation has a meaningful correlation with inner control in $95 \%$ confidence level and with behavioral section of entrepreneurial attitude in 99\% confidence level so. Furthermore, university type (non-athlete or Athlete University) has a meaningful correlation with sensational section of entrepreneurial attitude in $99 \%$ confidence level. 


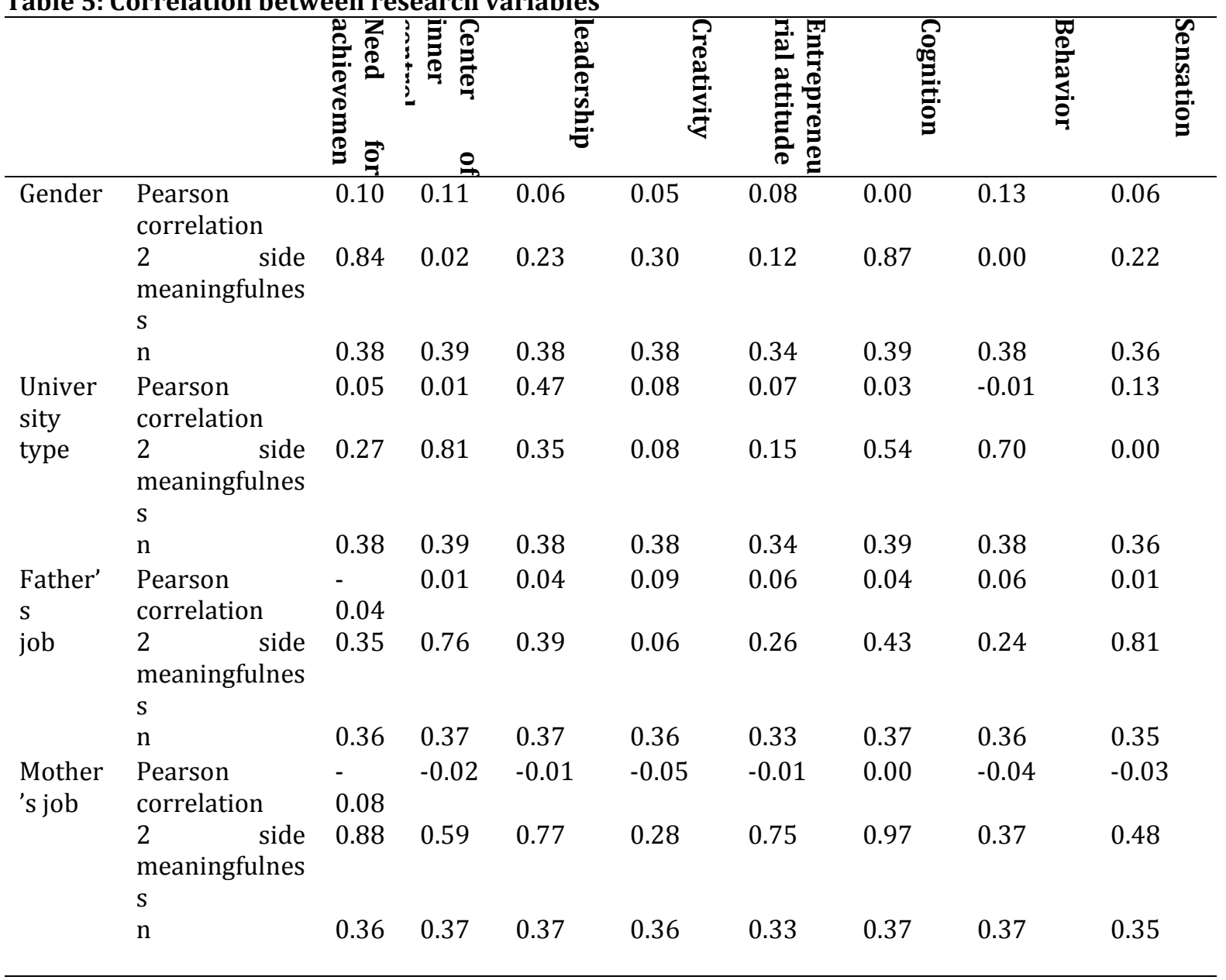

In order to investigate the effect of demographic variables in anticipation of entrepreneurship attitude, multiple regressions has been used. In this process, demographic variables (gender, university type and parent's occupation) were included. Table 6 shows these variables.

Table 6: Summary of multiple regression models (demographic variables)

\begin{tabular}{llllll}
\hline Model & $\mathbf{R}$ & R Square & $\begin{array}{l}\text { Adjusted } \\
\text { Square }\end{array}$ & $\begin{array}{l}\text { Std. Error of the } \\
\text { Estimate }\end{array}$ \\
\hline $\mathbf{1}$ & 0.103 & 0.011 & -0.002 & 7.898 \\
\hline
\end{tabular}

Results of regression model summery, shows that only $1 \%$ of entrepreneurship attitude changes by demographic variables have been described. Although the meaningfulness of regression and linear relation between variable have been shown in Table 9(analyses of variance). In following table, the meaningfulness has been shown as 0.494 , which means that regression is not meaningful here. Finally we can say: the effects of demographic variables on student's entrepreneurship attitude were not meaningful.

Table 7: Analysis of variance

\begin{tabular}{|c|c|c|c|c|c|c|}
\hline \multicolumn{2}{|c|}{ Model } & \multirow{2}{*}{$\begin{array}{l}\text { Sum square } \\
212.13 \\
\end{array}$} & \multirow{2}{*}{$\begin{array}{l}\begin{array}{l}\text { Degree of } \\
\text { freedom }\end{array} \\
4\end{array}$} & \multirow{2}{*}{$\begin{array}{l}\begin{array}{l}\text { Average } \\
\text { square }\end{array} \\
53.03\end{array}$} & \multirow{2}{*}{$\begin{array}{l}\mathbf{F} \\
0.850\end{array}$} & \multirow{2}{*}{$\begin{array}{l}\text { Meaningfulness } \\
0.494\end{array}$} \\
\hline 1 & Regression & & & & & \\
\hline & Residual & 19836.53 & 318 & 62.38 & & \\
\hline & Total & 20048.66 & 322 & & & \\
\hline
\end{tabular}




\section{Discussion and Conclusion}

Our findings show that, in all dimensions and components of entrepreneurship attitude, students' average scales are greater than average level. This finding consequently have supported the conclusion of other researches like Khedmati (2000) which have been defined that athlete university students have such a higher level of need for achievement and inner control compared to average. In addition, supporting the conclusion resulted in research done by Samadi \& Shirazi (2006) about entrepreneurial spirit of girl students in Esfahan. They found that entrepreneurial spirit indexes (creativity, self-confidence, and need for achievement, source of inner control, providence, and risk seeking) in students are higher than average level. In addition, the results of this research are in unisonous with finding of Henderson \& Robertson (2000) that assessed the juvenile's entrepreneurial attitude toward entrepreneurship in England. Generally, average scores of entrepreneurship attitude of male students were greater in all dimensions and components in compare to females, although this different is meaningful only about central inner control and behavioral dimensions. Can be proposed in this way that male students have such a higher central inner control and compare to female students, proposing higher level of entrepreneurial attitude in their behaviors. It seems that according to cultural factors, which sometimes play a deterrent role compare to females, females, comparing to males have such a weaker center of inner control and may fine lower level of possibility to propose entrepreneurial behaviors. Findings of this research concluded that there is no meaningfulness about effect of gender on entrepreneurship attitude so in this respect it is variant from finding of researches have been done by Kundu\& Rani (2008), Naffziger et al (1994), and Athayde (2009). Even if the entrepreneurial attitude average score of nonathlete university students is higher than athlete university students, but this different is not meaningful except in emotional section of entrepreneurial attitude. In this viewpoint, conclusion of present research is in compatible with research done by Samadi \& Shirazi (2006). They have found in their research that there is a meaningful difference about creation of entrepreneurial attitude between non-athlete university students and athlete university students. Findings have shown that having a self-occupied or business owner parents have no effect on students entrepreneurial attitudes, which is not in compatible with conclusions resulted by Naffziger et al. (1994) and Athayed (2009) which have known selfoccupancy of parents as an effective factor on entrepreneurial attitude. These research conclusions are in compatible with conclusion of research done by Jumaat et al. (2004). He found that there is no meaningful correlation between gender, race, parents occupation and students entrepreneurial attitude (Shariff,2009) .The findings of present research concluded that demographic variable (gender, university type, parents occupation) cannot present any considerable anticipation about entrepreneurial attitude of students. Then, it seems possible to be able to affect students entrepreneurial attitude by direct or indirect methods and by putting them on comfortable moderated environment in a positive way an also on time.

Suggestions: The results of this research have shown that non of the demographic variables have any meaningful effect on general entrepreneurial attitude of students, this fact can be considered as a remimder that shows necesity of attention to education for improve students entrepreneurial attitude. Thus, entrepreneurial attitude of students in this level should be put under special attention as a potential that will lead them to start a business entrepreneurially by doing entreprenurial actions. development of positive perseption of possibility and nicety of entrepreneurship by executing comfortable educations in lower ages, general improvement of entrepreneurship spirit in all public level, social strategic planing, policy and gole determination, appling comfortable methods, patterns and other applicable \& persuasive programs can be useful in this fild. Appropriate policies should be appliedthrough the use of this hidden potential. For example it is possible to grow students entrepreneurial knowledge by introdusing entrepreneurship as a method of occupqncy or create positive sensesion about entrepreneurship by introdusing benefits of self occupancy, entrepreneurship atractivness and its benefits.Moreover, it is possible to create an appropriate basis for improvement of entrepreneurial abilities and increase their confidency about their ability by executing and appling primary education about first level entrepreneurial skilles or during bookshops with small but applicable goals. Also by the help of confortable methods such as putting them under the challenge of teem working and other practical projects in universitys, we can create a appropriate environment for them to be able to express entrepreneurial attitude on behavioral demension. 


\section{References}

Ajzen, I. (1991). The theory of planned behavior. Organizational Behavior and Human Decision Processes, $50,179-211$.

Ajzen, I. \& Fishbein, M. (1977). Attitude-behavior relations: A theoretical analysis and review of empirical research. Psychological Bulletin, 84, 888-918.

Athayde, R. (2009). Measuring Enterprise Potential in Young People. Entrepreneurship Theory and Practice, 31(3), 387-406.

Brockhaus, R. H. (1982). The psychology of the entrepreneur. In C. A. Kent, D. L. Sexton, \& K. H. Vesper (Eds.), Encyclopedia of entrepreneurship, 39-71. Englewood Cliffs, NJ: Prentice Hall.

Caird, S. (1991).Testing enterprise tendency in occupational groups. British Journal of Management, 12, 177-186.

Carton, J. \& Nowicki, S. (1994). Antecedents of Individual Differences in Locus of Control of Reinforcement: A Critical Review. Genetic, Social \& General Psychology Monographs, 120(1), 3181.

Chio, A., Spreafico, R., Avanzini, G., Ghiglione, P., Vercellino, M. \& Mutani, R. (2003). Cesare Lombroso, cortical dysplasia, and epilepsy. Keen findings and odd theories. Neurology, 61, 1412-6.

Dahlgren, H. (1999). Entreprenorskap - Hur, vadochvarfor? (Entrepreneurship - how, what and why?), Rapport fran Institutet for Individan passed Skola Report of the Institute for Individualized University, Stockholm.

Drennan, J., Kennedy, J. \& Renfrow, P. (2004). The impact of childhood experiences on the development of entrepreneurial intentions. In: SEAANZ Brisbane 2004Entrepreneurship as the Way of the Future, 26 - 29 September 2004, QUT, Brisbane, and QLD.

Drucker, P. F. (1970). Entrepreneurship in business enterprise. Journal of Business Policy, 1, 10-11.

Florin, J., Karri, R. \& Rossiter, N. (2007). Fostering Entrepreneurial Drive in Business Education: An Attitudinal Approach. Journal of Management Education, 31, 17-42.

Fuchs, K., Werner, A. \& Wallau, F. (2008). Entrepreneurship education in Germany and Sweden: what role do different school systems play? Journal of Small Business and Enterprise Development, 15(2), 365-381.

Gasse, Y. (1985). A strategy for the promotion and identification of potential entrepreneurs at the secondary university level. In J. A. Homaday, B. Shils, J. A. Timmons, \& K. H. Vesper (Eds.), Frontiers of entrepreneurship research, 538-559. Wellesley, MA: Babson College.

Gibb, A. (1987). Enterprise culture-its meaning \& implications for education and training. Journal of European Industrial Training, 11(3), 2-38.

Gibb, A. (1993). The enterprise culture and education. International Small Business Journal, 11(3), 11-34.

Gibb, A. (2000). SME policy, academic research and the growth of ignorance: Mythical concepts, myths, assumptions, rituals and confusions. International Small Business Journal, 18(3/71), 13-35.

Gibb, A. (2002). In pursuit of a new enterprise and entrepreneurship paradigm for learning: Creative destruction, new values, new ways of doing thing and new combinations of knowledge. International Journal of Management Reviews, 4(3), 233-269.

Greenberger, D. B. \& Sexton, D. L. (1987). Leadership and entrepreneurship: New directions for venture initiation and success. In G. B. Roberts, H. Lasher, \& E. Maliche (Eds.), new ventures: Creation, development, support: The proceedings of the second annual conference of the United States Association for Small Business and Entrepreneurship, 52-57. Marietta, GA: Kennesaw College.

Henderson, R. \& Robertson, M. (2000). Who Wants To Be an Entrepreneur? Young Adult attitudes to entrepreneurship as a career. Career Development International, 5(6), 279-287.

Homaday, R. H. (1987). Small business managerial types and financial performance: Further evaluation of the Filley and Aldag instrument. Paper presented at the 1987 National Academy of Management meeting. August, New Orleans, LA,

Homaday, R. H. \& Nunnally, B. H. (1987).Decisions styles of black small business owners: A replication. Paper presented at the 1987 National Academy of Management meeting, August, New Orleans, LA.

Johannisson, B. \& Madsen, T. (2000). Aha! Foretag samtlarande (Aha! Entrepreneurial learning), Utbildningsradion, Orebro.

Jumaat, A. M., RahmanI, H. A. \& Salleh, M. F. (2004). A study on entrepreneurial attitudes among youths in Malaysia. Case study: Institute Kemahiran Belia Negara, Malaysia. Journal of American Academy of Business, 4, 192-197. 
Khedmati, T. S. (2000). Investigated the occurrence and development of entrepreneurs in the field of boys' high school of state work and Knowledge City of Karaj, administrators, teachers and students, the Master of Science Thesis Tehran University Education.

Kundu, S. \& Rani, S. (2008). Human resources entrepreneurial attitude orientation by gender and background: a study of Indian Air Force trainees. International Journal of Management and Enterprise Development, 5(1), 77-101.

Liñán, F., Urbano, D. \& Guerrero, M. (2010). Regional variations in entrepreneurial cognitions: Start-up intentions of university students in Spain. Entrepreneurship and Regional Development, 23(3-4), 187-215.

Mednick, A. (1996). Journeys through our classrooms. Dubuque, IA: Kendal/Hunt.

Naffziger, D. W., Hornby, J. S. \& Kuratko, D. F. (1994). A proposed research model of entrepreneurial motivation. Entrepreneurship Theory and Practice, 17(1), 49-55.

Norasmah, O., Ahmad, A. M., Ariffin, M. F. \& Jani, M. (2008). Entrepreneurial Studies in Institutions of Higher Learning. In Research on Higher Education Policy: Enhancing Education Quality. Publication of the Ministry of Higher Education Malaysia.

Northouse, G. (2007). Leadership theory and practice. (3rd Ed.) Thousand Oak, London, New Delhi, Sage Publications, Inc.

Olson, P. D. \& Bosserman, D. A. (1984). Attributes of the entrepreneurial type. Business Horizons, 3, 53-56.

Rasheed, H. S. (2000). Developing Entrepreneurial Potential in Youth: The Effects of Entrepreneurial Education and Venture Creation. United States association of small business and entrepreneurship (USASBE) Annual National Conference.

Robinson, P. B., Stimpson, D. V., Huefner, J. C. \& Hunt, H. K. (1991). An attitude approach to the prediction of entrepreneurship. Entrepreneurship Theory and Practice, 15, 13-31.

Rosenberg, M. J. \&Holland, C. I. (1960). Cognitive, affective, and behavioral components of attitudes. In M. J. Rosenberg, C. I. Hovland, W. J. McGuire, R. P. Abelson, \& J. W. Brehm (Eds.), Attitude organization and change: An analysis of consistency among attitude components. New Haven, CT: Yale University.

Samadi, C. \& ShirazdiIsfahani, H. (2006). Principles of citizenship education and the processes in Iran. Journal of Education innovation, 16, 165-187.

Schwarz, E. J., Wdowiak, M. A., Almer-Jarz, D. A. \& Breitenecker, R. J. (2009). The effects of attitudes and perceived environment conditions on students' entrepreneurial intent. Education + Training, 51(4), 272-291.

Shane, S. (2007). A General Theory of Entrepreneurship.USA: Edward Elgar.

Shapero, A. (1984). The entrepreneurial event. In C.A. Kent (Ed.), The Environment for entrepreneurship (21-40). Lexington, MA: C.D. Health.

Shariff, M. \& Saud, M. B. (2009). An Attitude Approach to the Prediction of Entrepreneurship on Students at Institution of Higher Learning in Malaysia. International Journal of Business and Management, $4(4), 129-135$.

Stewart, W. H., Watson, W. E., Carland, J. A. \& Carland, J. W. (1998). A proclivity for entrepreneurship: A comparison of entrepreneurs, small business owners and corporate managers. Journal of Business Venturing, 14, 189-214.

Timmons, J. A. \& Spinelli, S. (2004). New venture creation: Entrepreneurship for the 21st century (6th Ed).Boston: McGraw-Hill.

Wilder, B. (1989). Implication of the current theory of achievement motivation. Psychology in University, $8,164-171$. 